\title{
Development of directly compressible metformin hydrochloride by the spray-drying technique
}

\author{
BHAVESH S. BAROT ${ }^{1, *}$ \\ PUNIT B. PAREJIYA ${ }^{1}$ \\ TUSHAR M. PATEL ${ }^{2}$ \\ RAJESH K. PARIKH ${ }^{2}$ \\ MUKESH C. GOHEL ${ }^{2}$
${ }^{1}$ K. B. Institute of Pharmaceutical
Education and Research
Gh-6 Road, Sector - 23
Gandhinagar-382023
Gujarat, India \\ ${ }^{2}$ L. M. College of Pharmacy \\ Opp. Gujarat University \\ Navrangpura, Ahmedabad-380009 \\ Gujarat, India
}

\begin{abstract}
Metformin hydrochloride exhibits poor compressibility during compaction, often resulting in weak and unacceptable tablets with a high tendency to cap. The purpose of this study was to develop directly compressible metformin hydrochloride by the spray-drying technique in the presence of polymer. Metformin hydrochloride was dissolved in solutions containing a polymer, namely polyvinylpyrrolidone (PVP K30), in various concentrations ranging from $0-3 \%(m / V)$. These solutions were employed for spray-drying. Spray-dried drug was evaluated for yield, flow property and compressibility profile. Metformin hydrochloride spray-dried in the presence of $2 \%$ PVP K30 showed an excellent flow property and compressibility profile. From the calculated Heckel's parameter $(P y=2.086)$, it was demonstrated that the treated drug showed better particle arrangement in the initial compression stage. Kawakita analysis revealed better packability of the treated drug compared to the untreated drug. Differential scanning calorimetry and Fourier transform infrared spectroscopy experiments showed that the spray-dried drug did not undergo any chemical modifications. Tablets made from the spray-dried drug $(90 \%, \mathrm{~m} / \mathrm{m})$ were evaluated for crushing strength, friability and disintegration time and the results were found satisfactory.
\end{abstract}

Keywords: metformin hydrochloride, direct compression, spray drying

Direct compression, although simple in terms of the unit operations involved, is highly influenced by powder characteristics such as flowability, compressibility and dilution potential. Tablets consist of active drugs and excipients, and no drug substance or excipient possesses all the desired physico-mechanical properties required for the development of a robust direct-compression manufacturing process, which could be smoothly scaled from the laboratory to production scale. Most formulations (70-80\%) contain ex-

*Correspondence; e-mail: bhaveshbarot83@gmail.com 
cipients at a higher concentration than the active drug. But this concept could be erroneous for drugs requiring a high dose and of poor compressibility, since this might increase the final mass of tablet beyond acceptable limits (1). Metformin hydrochloride is a typical example of this type of drugs. Metformin hydrochloride is an oral anti-hyperglycemic agent of the biguanide class used in the treatment of non-insulin dependent diabetes mellitus (2). Metformin hydrochloride is highly water soluble (>300 $\mathrm{mg} \mathrm{mL}^{-1}$ at $25{ }^{\circ} \mathrm{C}$ ), hygroscopic and shows stability problems. Consequently, it is necessary to provide a free-flowing and cohesive metformin hydrochloride capable of being directly compressed into strong tablets with an acceptable in vitro dissolution profile (3). It is desirable to produce drug crystals with improved compaction properties and suitable for direct compression. The presence of small amounts of an effective additive in the crystallization medium can dramatically change the crystal size and shape. There are several reports of attempts to change the crystal habit of a particular substance in the presence of additives during crystallization processes (4-8).

Spray-drying converts a liquid into powder in a one-step process, producing fine, dustless or agglomerated powders, usually approximately spherical with a narrow size range and generally hollow. The hollow nature imparts low bulk density to powders (9). Spray-drying can also modify the crystalline content of the material. The aim of the present work was to spray-dry metformin hydrochloride in the presence of a polymer, whereby it was supposed to modify the physical properties of the drug by altering its crystal shape to render it directly compressible.

\section{EXPERIMENTAL}

\section{Materials}

Metformin hydrochloride was obtained as a gift sample from Lincoln Pharmaceuticals (India). Polyvinylpyrrolidone (PVP K30) was purchased from Laser Laboratories (India) and microcrystalline cellulose (Avicel PH 101) was obtained from Intas Pharma (India).

\section{Spray-drying}

Spray-drying procedure employed is similar to the crystallization procedure adopted earlier by Ford et al. (4). Samples of metformin hydrochloride (150 g) were dissolved in solutions ranging from $0,1,1.5,2,2.5$ to $3 \%(m / V)$ of PVP K30 (batch MP1-MP6), each solution of $500 \mathrm{~mL}$. The resulting mixtures were thoroughly mixed to get complete solution. Spray-drying was carried out on a laboratory scale mini-spray drier (Jay Instrument and System Pvt. Ltd., Lab Equipment Division, India). Spray-drying was done as per the operating conditions in Table I. Spray-dried powders were then stored in a desiccator for 2 hours before use. The powders were then weighed to calculate the $\%$ yield. 
B. S. Barot et al: Development of directly compressible metformin hydrochloride by the spray-drying technique, Acta Pharm. 60 (2010) 165-175.

Table I. Spray-drying operating conditions

\begin{tabular}{lc}
\hline \multicolumn{2}{c}{ Operating conditions } \\
\hline Inlet temperature & $160{ }^{\circ} \mathrm{C}$ \\
Outlet temperature & $115{ }^{\circ} \mathrm{C}$ \\
Pressure & $2 \mathrm{~kg} \mathrm{~cm}^{-2}$ \\
Feed rate & $5-10 \mathrm{~mL} \mathrm{~min}^{-1}$ \\
Atomization & $100 \%$ \\
\hline
\end{tabular}

\section{Flow property and compressibility profile}

Bulk density was determined as a quotient of mass to volume of the sample. Tapped density was determined using a USP tap density tester (ETD - 1020, Electrolab Pvt. Ltd., India). Percent compressibility (Carr's index) was determined as one hundred times the ratio of the difference between tapped density and bulk density to tapped density $(10,11)$. The angle of repose was determined using a fixed height funnel method (11).

\section{Compressibility behavior by the Heckel equation}

The compressibility behaviour of untreated and spray-dried metformin hydrochloride was evaluated by the Heckel equation. Powders ( $800 \mathrm{mg}$ ) were compressed in a $\mathrm{KBr}$ press (Wika Quality Systems, Germany) using 13-mm flat faced punches and a matching die at the force of 5, 10, 15, 20, 25 and $30 \mathrm{kPa}$ for 5 seconds. Tablets were stored in an air-tight container for 24 hours to enable elastic recovery to occur. Diameter and thickness of the tablets were determined. The data was processed using the Heckel equation $(12,13)$ :

$$
\ln \left(\frac{1}{1-D}\right)=k P+A
$$

in which $k$ and $A$ are constants and $D$ and $P$ are the packing fraction (relative density) and pressure, respectively. The mean yield pressure $(P y)$, derived from the reciprocal of slope $k$, was obtained by regression analysis of the linear portion of the plot.

\section{Packability by the Kawakita equation}

Packability was evaluated by tapping the spray-dried powder of the optimized batch in a measuring cylinder. The data was analyzed using the Kawakita equation (14):

$$
\frac{n}{c}=\frac{1}{a b}+\frac{n}{a}
$$


where:

$$
\begin{aligned}
& a=\frac{V_{o}-V_{\mathrm{inf}}}{V_{o}} \\
& b=\frac{V_{o}-V_{n}}{V_{o}}
\end{aligned}
$$

in which $a$ and $b$ are constants, $n$ is the tap number and $V_{0}, V_{n}$, and $V_{\text {inf }}$ are the powder bed volumes at initial, after $n$th tapping $(5,10,15,20,25,50,75,100,200,300$ and 400) and at equilibrium state (500th tap), respectively.

\section{Fourier-transform infrared spectroscopy (FTIR)}

FTIR study was performed on spray-dried samples to determine the interaction between metformin hydrochloride and PVP K30 or any change in the drug structure upon the treatment employed. Spray-dried powder of the optimized batch was mixed separately with IR grade potassium bromide $(\mathrm{KBr})$. This mixture was scanned over a wave number range of 4000 to $400 \mathrm{~cm}^{-1}$ using a Fourier transform infrared spectrophotometer (Model FTIR-8400S, Shimadzu, Japan) and overlay spectra were recorded.

\section{Differential scanning calorimetry (DSC)}

DSC study of untreated and spray-dried metformin hydrochloride samples were carried out on a differential scanning calorimeter (model DSC7, Perkin Elmer, UK). Samples, of $2 \mathrm{mg}$ each, of untreated drug and spray-dried powder of the optimized batch were held for 1 minute at $50{ }^{\circ} \mathrm{C}$ and then heated gradually at $10{ }^{\circ} \mathrm{C} \mathrm{min}-1$ in crimped aluminum pans under a nitrogen atmosphere from 50 to $270{ }^{\circ} \mathrm{C}$. The onsets of melting points and enthalpies of fusion of samples were automatically calculated by the instrument.

\section{Scanning electron microscopy (SEM)}

Electron micrographs of untreated and spray-dried metformin hydrochloride were obtained using a scanning electron microscope (model JSM T200, Jeol Ltd., Japan). The specimens were coated under vacuum with gold in an argon atmosphere prior to observation. The scanning electron microscope was operated at an acceleration voltage of 30 $\mathrm{kV}$.

\section{Moisture uptake}

Spray-dried powder $5 \mathrm{~g}$ was uniformly spread on a glass Petri-dish, which was stored at $75 \%$ relative humidity in a desiccator at room temperature. The percentage increase in powder mass was noted after 48 hours. 
B. S. Barot et al:: Development of directly compressible metformin hydrochloride by the spray-drying technique, Acta Pharm. 60 (2010) 165-175.

\section{Preparation of tablets with the spray-dried drug}

Tablets containing $500 \mathrm{mg}$ of the spray-dried powder of the optimized batch making $90 \%(\mathrm{~m} / \mathrm{m})$ of the total tablet mass, microcrystalline cellulose $7 \%(\mathrm{~m} / \mathrm{m})$, magnesium stearate $2 \%(\mathrm{~m} / \mathrm{m})$ and talc $1 \%(\mathrm{~m} / \mathrm{m})$ were compressed on a single punch tablet machine (Cadmach Machinery Pvt. Ltd, India).

\section{Evaluation of tablets for crushing strength, friability and disintegration time}

Crushing strength was determined by a Dr. Schleuniger ${ }^{\circledR}$ hardness tester (Pharmatron $8 \mathrm{M}$, Germany). Friability was evaluated as percent mass loss of 20 tablets tumbled in a friabilator (model EF2, Electrolab Pvt. Ltd., India) for $4 \mathrm{~min}$ at $25 \mathrm{rpm}$. The tablets were then de-dusted, and the loss in mass caused by the fracture or abrasion was recorded as percentage friability. A disintegration test (model ED2, Electrolab Pvt. Ltd., India) was performed on six tablets at $37^{\circ} \mathrm{C}$ in $900 \mathrm{~mL}$ of distilled water in accordance with the United States Pharmacopoeia 29 (15).

\section{RESULTS AND DISCUSSION}

\section{Percentage yield}

Percentage yield of spray-dried metformin hydrochloride decreased with an increase in the concentration of PVP K30; nearly all the batches had the yield $>70 \%$. Batch MP1 showed the highest yield of $84 \%$, while batch MP6 showed the lowest yield of $71 \%$.

\section{Flow property and compressibility profile}

Spray-drying of pharmaceuticals provided great improvement to the flow property. This is due to the fact that the needle shape crystals of pure metformin hydrochloride changed to spherical shape. Such crystals can easily glide over each other and improve the flow. There was also a decrease in angle of repose and Carr's index from batches MP1 to MP4 and an increase in batches MP5 and MP6 (Table II). Initially, PVP K30 aided

Table II. PVP K30 solutions for spray-drying, flowability and compressibility profile

\begin{tabular}{ccccc}
\hline Batch $^{\text {a }}$ & $\begin{array}{c}\text { PVP K30 } \\
(\%, m / V)\end{array}$ & $\begin{array}{c}\text { Yield } \\
(\%)\end{array}$ & $\begin{array}{c}\text { Angle of repose } \\
\left({ }^{\circ}\right)\end{array}$ & Carr's index \\
\hline MP1 & 0 & 84 & 44 & 28 \\
MP2 & 1 & 77 & 38 & 23 \\
MP3 & 1.5 & 75 & 35 & 18 \\
MP4 & 2 & 75 & 30 & 13 \\
MP5 & 2.5 & 72 & 32 & 19 \\
MP6 & 3 & 71 & 36 & 25 \\
\hline
\end{tabular}

a Batches contained $150 \mathrm{~g}$ of metformin hydrochloride. 
B. S. Barot et al:: Development of directly compressible metformin hydrochloride by the spray-drying technique, Acta Pharm. 60 (2010) 165-175.

in reducing the particle size, but as its concentration increased beyond $2 \%(\mathrm{~m} / \mathrm{V})$, the spray-dried material became sticky and tended to retain the moisture. Thus, batch MP4 spray-dried with $2 \%$ PVP K30 was considered as the optimized batch as it showed an angle of repose of $30^{\circ}$ and Carr' index 13.

\section{Compressibility behavior by the Heckel equation}

Data obtained over a range of compression force from 5 to $30 \mathrm{kPa}$ was analyzed by applying the Heckel equation. The yield pressure was then calculated from the reciprocal of the slope $k$ of the regression line. Heckel reports that the linear portion of the plot (Fig. 1) represents the densification process by particle deformation after interparticle bonding, and thus soft, ductile powders have lower yield pressure. Powders that have the lowest value of $P y$ undergo plastic deformation as a result of the rebonding of primary crystals that are smaller than those of the original powder. Py reflects the compression characteristics of the material; the lesser the value of $P y$, the greater the tendency towards plastic deformation $(12,13)$. As shown in Table III, spray-dried metformin hydrochloride shows greater plastic deformation due to the presence of PVP K30. Untreated metformin hydrochloride compacts broke apart as soon as pressure was released in the KBr press.

Table III. Heckel analysis of spray-dried metformin hydrochloride (batch MP4)

\begin{tabular}{|c|c|c|c|c|c|c|}
\hline $\begin{array}{c}\text { Compression } \\
\text { force }(\mathrm{kPa})\end{array}$ & $\begin{array}{l}\text { Thickness } \\
(\mathrm{mm})^{\mathrm{a}}\end{array}$ & $\begin{array}{l}\text { Volume } \\
\left(\mathrm{mm}^{3}\right)^{\mathrm{a}, \mathrm{b}}\end{array}$ & $\begin{array}{l}\text { Density } \\
\left(\mathrm{g} \mathrm{mm}^{-3}\right)^{\mathrm{a}}\end{array}$ & $\begin{array}{l}\text { Relative } \\
\text { densitya,d }\end{array}$ & Porosity ${ }^{\mathrm{a}, \mathrm{e}}$ & $\ln [1 / \text { porosity }]^{a}$ \\
\hline 0 & 0 & 0 & - & - & - & 0 \\
\hline 5 & $5.45 \pm 0.01$ & $707.53 \pm 1.30$ & $1.13 \pm 0.01$ & $0.93 \pm 0.01$ & $0.07 \pm 0.01$ & $2.64 \pm 0.02$ \\
\hline 10 & $5.33 \pm 0.03$ & $691.96 \pm 3.27$ & $1.15 \pm 0.01$ & $0.95 \pm 0.01$ & $0.05 \pm 0.01$ & $2.99 \pm 0.09$ \\
\hline 15 & $5.27 \pm 0.02$ & $684.17 \pm 2.60$ & $1.17 \pm 0.01$ & $0.96 \pm 0.01$ & $0.04 \pm 0.01$ & $3.22 \pm 0.09$ \\
\hline 20 & $5.23 \pm 0.01$ & $678.97 \pm 1.30$ & $1.18 \pm 0.01$ & $0.97 \pm 0.01$ & $0.03 \pm 0.01$ & $3.43 \pm 0.06$ \\
\hline 25 & $5.19 \pm 0.02$ & $673.78 \pm 2.60$ & $1.19 \pm 0.01$ & $0.97 \pm 0.01$ & $0.03 \pm 0.01$ & $3.69 \pm 0.15$ \\
\hline 30 & $5.17 \pm 0.01$ & $671.18 \pm 1.30$ & $1.19 \pm 0.01$ & $0.98 \pm 0.01$ & $0.02 \pm 0.01$ & $3.85 \pm 0.09$ \\
\hline 40 & $5.06 \pm 0.02$ & $656.90 \pm 1.98$ & $1.21 \pm 0.01^{\mathrm{c}}$ & - & - & - \\
\hline
\end{tabular}

Regression analysis of the linear portion of the curve between pressure and $\ln$ [1/porosity] slope $k=0.4792$, intercept $A=2.463$

Mean yield pressure $\left(P_{y}\right)=1 / \mathrm{k}=1 / 0.4792=2.086$

\footnotetext{
a Mean \pm standard deviation, $n=3$.

$\mathrm{b}$ Volume of cylinder is $\pi \mathrm{r}^{2} \mathrm{~h}$ (average diameter $=12.86 \mathrm{~mm}$ ).

c True density.

d Relative density: density/true density.

e Porosity: 1 - relative density.
} 


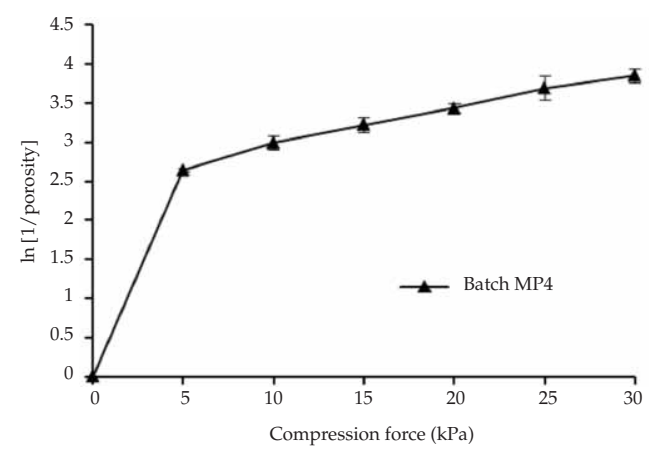

Fig. 1. Heckel plot for spray-dried metformin hydrochloride (mean $\pm \mathrm{SD}, n=3$ ).

\section{Packability behavior by the Kawakita equation}

Packabilty was ascertained by comparing the constants $a$ and $b$ of the Kawakita equation. Constant $a$ represents the proportion of consolidation as the closest packing is attained. Constant $a$ of batch MP4 (0.316) is smaller than that of the untreated drug (0.357). This result shows that the spray-dried drug showed good packing even without tapping. The reciprocal of $b$ represents the packing velocity. Higher $b$ value of the spray-dried drug (0.0984) than that of the untreated drug (0.0683) proved that tapping velocity of the treated drug was slower than that of the untreated drug (Table IV) (14).

\section{Physical characterization of spray-dried metformin hydrochloride}

FTIR studies revealed that metformin hydrochloride showed two typical bands at 3369 and $3296 \mathrm{~cm}^{-1}$ due to N-H primary stretching vibration and a band at $3170 \mathrm{~cm}^{-1}$ due to N-H secondary stretching, and characteristics bands at 1626 and $1567 \mathrm{~cm}^{-1}$ assigned to $\mathrm{C}=\mathrm{N}$ stretching. No significant shifts of reduction in intensity of the FTIR bands of metformin hydrochloride were observed in the spray-dried product.

DSC thermogram (Fig. 2) showed that spray-dried powder of the optimized batch (MP4) and untreated drug have a sharp melting point with a flat base-line, which indicated that no events such as hydration, solvation or polymorphic transition had occurred during the treatment. DSC studies show that the onsets of melting point $\left(T_{\mathrm{m}}\right)$ of untreated and spray-dried drugs are $232.092{ }^{\circ} \mathrm{C}$ and $229.732{ }^{\circ} \mathrm{C}$, respectively. Enthalpies of fusion $\left(\Delta H_{\mathrm{f}}\right)$ of untreated and spray-dried drugs are $318.989 \mathrm{~J} \mathrm{~g}^{-1}$ and $295.381 \mathrm{~J} \mathrm{~g}^{-1}$, respectively. Thus, on spray-drying $T_{\mathrm{m}}$ of metformin hydrochloride decreased by $2.4{ }^{\circ} \mathrm{C}$ and $\Delta H_{\mathrm{f}}$ decreased by $23.608 \mathrm{~J} \mathrm{~g}^{-1}$. These reductions in the onset of the melting point and enthalpies of fusion may be attributed to the reduction in the drug crystal size, or to weakening and disruption of the crystal lattice and order. This may be attributed to an interaction between metformin hydrochloride and PVP K30, resulting in a change in physical properties of the crystals (4).

SEM micrographs (Fig. 3) indicate needle-shaped and relatively large size crystals of metformin hydrochloride. The needle-shaped crystals of the untreated drug are responsible for its poor compressibility, while the micrographs of the spray-dried drug show a reduction in size and change into an almost spherical shape. The spherical shape 
B. S. Barot et al.: Development of directly compressible metformin hydrochloride by the spray-drying technique, Acta Pharm. 60 (2010) 165-175.

Table IV. Kawakita analysis

\begin{tabular}{|c|c|c|c|c|c|c|}
\hline \multirow{2}{*}{$\begin{array}{l}\text { No. of } \\
\text { taps }(n)\end{array}$} & \multicolumn{2}{|c|}{ Volume } & \multicolumn{2}{|c|}{ c } & \multicolumn{2}{|c|}{$n / c$} \\
\hline & $\begin{array}{l}\text { Untreated } \\
\text { Met } \cdot \mathrm{HCl}\end{array}$ & Batch MP4 & $\begin{array}{l}\text { Untreated } \\
\text { Met } \cdot \mathrm{HCl}\end{array}$ & Batch MP4 & $\begin{array}{l}\text { Untreated } \\
\text { Met } \cdot \mathrm{HCl}\end{array}$ & Batch MP4 \\
\hline 0 & $42^{\mathrm{a}}$ & $38^{\mathrm{a}}$ & - & - & - & - \\
\hline 5 & 39 & 35 & 0.071 & 0.078 & 70 & 63.33 \\
\hline 10 & 37 & 33 & 0.119 & 0.131 & 84 & 76 \\
\hline 15 & 34 & 31 & 0.190 & 0.184 & 78.75 & 81.43 \\
\hline 20 & 33 & 30 & 0.214 & 0.210 & 93.33 & 95 \\
\hline 25 & 32 & 29 & 0.238 & 0.237 & 105 & 105.55 \\
\hline 50 & 30 & 28 & 0.286 & 0.263 & 175 & 190 \\
\hline 75 & 29 & 27 & 0.309 & 0.289 & 242.31 & 259.09 \\
\hline 100 & 28 & 26 & 0.333 & 0.316 & 300 & 316.66 \\
\hline 200 & 27 & 26 & 0.357 & 0.316 & 560 & 633.33 \\
\hline 300 & 27 & 26 & 0.357 & 0.316 & 840 & 950 \\
\hline 400 & 27 & 26 & 0.357 & 0.316 & 1120 & 1266.6 \\
\hline 500 & 27 & 26 & 0.357 & 0.316 & 1400 & 1583.3 \\
\hline \multicolumn{7}{|c|}{ Regression analysis between $n$ and $n / c$ : slope $=1 / a$, intercept $=1 / a b$} \\
\hline \multicolumn{3}{|c|}{ Metformin hydrochloride: } & & \multicolumn{3}{|c|}{ Batch MP4 } \\
\hline $\begin{array}{c}\text { Slope }=2.691 \\
a=0.357\end{array}$ & \multicolumn{2}{|c|}{$\begin{array}{c}\text { Intercept }=41.037 \\
b=0.06825\end{array}$} & & $\begin{array}{c}\text { Slope }=3.079 \\
a=0.316\end{array}$ & \multicolumn{2}{|c|}{ Intercept $=32.159$} \\
\hline
\end{tabular}

Met $\cdot \mathrm{HCl}$ : metformin hydrochloride.

a Initial bulk volume $\left(V_{0}\right)$.

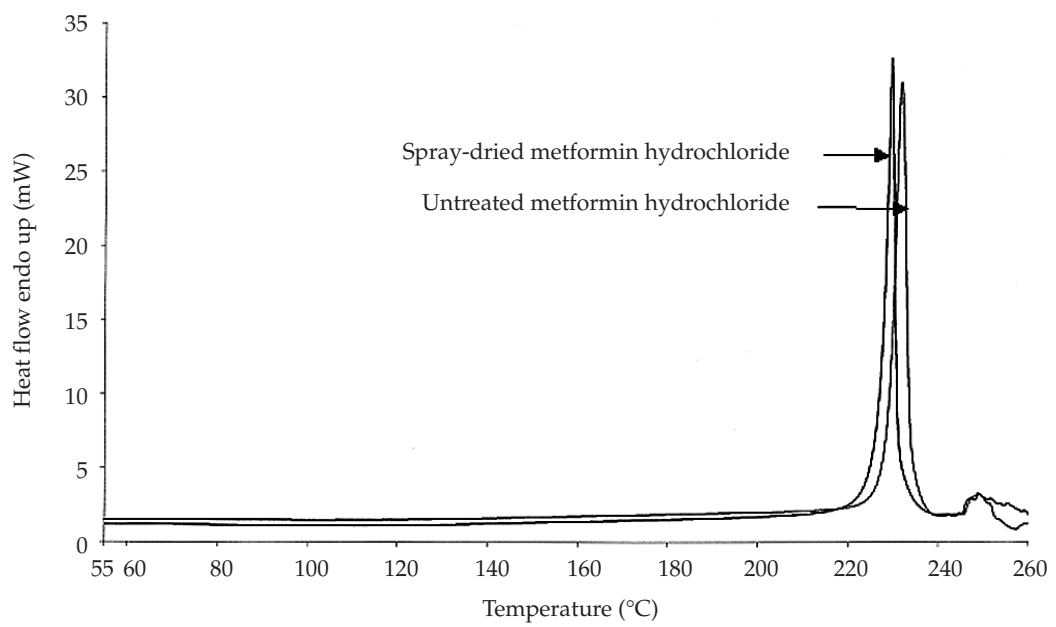

Fig. 2. DSC thermogram of spray-dried and untreated metformin hydrochloride. 
B. S. Barot et al.: Development of directly compressible metformin hydrochloride by the spray-drying technique, Acta Pharm. 60 (2010) 165-175.
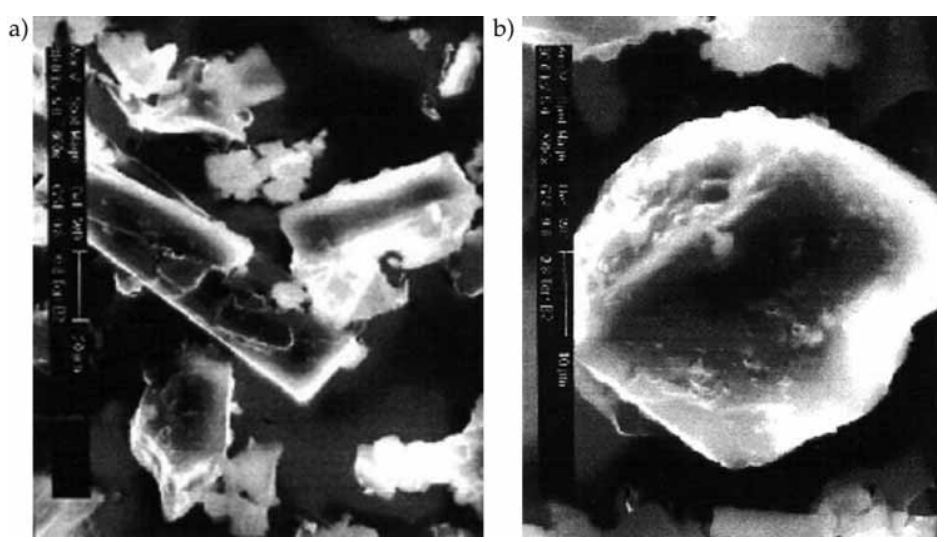

Fig. 3. Micrographs of: a) untreated and b) spray-dried metformin hydrochloride (batch MP4).

of the spray-dried particles is responsible for good compressibility and flowability of metformin hydrochloride. PVP K30 changes the shape of metformin hydrochloride particles and deposits forming a thin coat over them, so as to cause the formation of small agglomerates which help in the conversion of a poorly compressible drug into a directly compressible drug.

\section{Moisture uptake}

Spray-dried metformin hydrochloride sample showed a mass gain of $14 \%$ after 48 hours. Metformin hydrochloride is inherently a hygroscopic material and PVP K30 also absorbs the moisture. Thus, the treated drug is hygroscopic in nature and should be stored in air-tight containers.

\section{Crushing strength, friability and disintegration test of tablets}

Tablets made from spray-dried metformin hydrochloride displayed satisfactory crushing strength above $70 \mathrm{~N}$ and good friability $(<0.65 \%)$. The average mass of the tablets was $555.1 \pm 2.4 \mathrm{mg}, n=10$, and the disintegration time of tablets was 6 minutes.

\section{CONCLUSIONS}

It was found that PVP is an effective additive during spray-drying, which has a significant effect on the crystal formation and crystal habit of metformin hydrochloride. These effects were attributed to adsorption of PVP onto the surfaces of growing crystals of the drug. Metformin hydrochloride spray-dried in the presence of $2 \%(\mathrm{~m} / \mathrm{V})$ of PVP K30 showed good flowability and compressibility. Heckel analysis revealed that the spray-dried drug underwent plastic deformation, and Kawakita analysis revealed better packability of the treated drug. FTIR and DSC studies showed that the spray-dried drug 
B. S. Barot et al:: Development of directly compressible metformin hydrochloride by the spray-drying technique, Acta Pharm. 60 (2010) 165-175.

did not undergo chemical modifications compared to the untreated drug. Moisture uptake studies revealed the hygroscopic nature of the spray-dried drug. Tablets made from the spray-dried drug showed acceptable crushing strength, friability and disintegration time.

The technique of spray-drying is applicable to the drugs requiring a high dose and of poor compressibility. On spray-drying, the amount of directly compressible diluent could be minimized in the tablet formulation, which will decrease the tablet mass. Furthermore this approach could be useful for designing directly compressible sustained release tablet formulations, allowing a formulator to use a higher amount of matrixing polymer instead of a directly compressible diluent.

Acknowledgements. - We are thankful to Lincoln Pharmaceuticals, Gandhinagar, India, for providing metformin hydrochloride as a gift sample. Kind co-operation with the Sophisticated Instrumentation Center for Applied Research and Testing (SICART) Vallabh Vidyanagar, India, for SEM and DSC studies is appreciated.

\section{REFERENCES}

1. R. F. Shangraw, Compressed Tablets by Direct Compression, in Pharmaceutical Dosage Forms: Tablets (Eds. H. A. Leiberman, L. Lachman and J. B. Schwatz), Marcel Dekker, New York 1990, pp. 195-246.

2. D. Stepensky, M. Friedman, W. Srour, I. Raz and A. Hoffman, Preclinical evaluation of pharmacokinetic-pharmacodynamic rationale for oral CR metformin formulation, J. Control. Rel. 71 (2001) 107-115; DOI: 10.1016/S0168-3659(00)00374-6.

3. O. Defang, N. Shufang, L. Wei, G. Hong, L. Hui and P. Weisan, In-vivo and in-vitro evaluation of two extended release preparations of combination metformin and glipizide, Drug Dev. Ind. Pharm. 31 (2005) 677-685; DOI: 10.1080/03639040500216410.

4. J. L. Ford, H. A. Garekani, M. H. Rubinstein and A. Rajabi-Siahboomi, Highly compressible paracetamol-I: Crystallization and characterization, Int. J. Pharm. 208 (2000) 87-99; DOI: 10.1016/ S0378-5173(00)00550-0.

5. J. R. Davey, The role of additives in precipitation processes, in Industrial Crystallization (Eds. S. J. Jancic and E. J. De Jong), Elsevier, Amsterdam 1982, pp. 123-135.

6. A. S. Michaels and A. R. Colville, The effect of surface active agents on crystal growth rate and crystal habit, J. Phys. Chem. 64 (1960) 13-19; DOI: 10.1021/j100830a005.

7. J. Broadhead, S. K. Edmond Rouan and C. T. Rhodes, The spray drying of pharmaceuticals, Drug Dev. Ind. Pharm. 18 (1992) 1169-1206; DOI: 10.3109/03639049209046327.

8. A. Nokhodchi, N. Bolourtchian and R. Dinarvand, Crystal modification of phenytoin using different solvents and crystallization conditions, Int. J. Pharm. 250 (2003) 85-97; DOI: 10.1016/ S0378-5173(02)00488-X.

9. P. D. Martino, M. Scoppa, E. Jorris, G. F. Palmieri, C. Andres, Y. Pourcelot and S. Martelli, The spray drying of acetazolamide as method to modify crystal properties and to improve compression behaviour, Int. J. Pharm. 213 (2001) 209-221; DOI: 10.1016/S0378-5173(00)00675-X.

10. R. L. Carr, Evaluating flow properties of solids, Chem. Eng. 72 (1965) 163-168.

11. J. Staniforth, Powder flow, in Pharmaceutics: The Science of Dosage Form Design (Ed. M. E. Aulton), 2nd ed., Churchill Livingstone, London 2002, pp. 197-210.

12. R. W. Heckel, Density-pressure relationship in powder compaction, Trans. Metal. Soc. AIME 221 (1961) 671-675. 
B. S. Barot et al:: Development of directly compressible metformin hydrochloride by the spray-drying technique, Acta Pharm. 60 (2010) 165-175.

13. R. W. Heckel, An analysis of powder compaction phenomena, Trans. Metal. Soc. AIME 221 (1961) 1001-1008.

14. K. Kawakita and K. H. Ludde, Some consideration of powder compression equations, Powder Tehnol. 4 (1971) 61-68; DOI: 10.1016/0032-5910(71)80001-3.

15. United States Pharmacopoeia 29, National Formulary 24, USP Convention, Rockville 2006.

\section{$S A \check{Z} E T A K$}

\section{Razvoj metformin hidroklorida za izravnu kompresiju metodom sušenja raspršivanjem}

BHAVESH S. BAROT, PUNIT B. PAREJIYA, TUSHAR M. PATEL, RAJESH K. PARIKH i MUKESH C. GOHEL

Metformin hidroklorid se teško komprimira zbog čega nastaju slabe tablete neodgovarajuće kvalitete s velikom tendencijom kalanja. Cilj ovog rada je prirediti metformin hidroklorid za izravnu kompresiju metodom sušenja raspršivanjem u prisutnosti polimera. Metformin hidroklorid je otopljen uz dodatak različitih količina $(0-3 \% \mathrm{~m} / \mathrm{V})$ polivinilpirolidona (PVP K30). Dobivene otopine sušene su raspršivanjem, a tako pripravljenom metformin hidrokloridu određivano je iskorištenje, tečnost i kompresibilnost. Metformin hidroklorid pripravljen u prisutnosti $2 \%$ PVP K30 ima izvrsnu tečnost i kompresibilnost. Izračunati Heckelovi parametri $\left(P_{y}=2,086\right)$ pokazuju da tako obrađeni metformin hidroklorid tvori veće čestice na početku kompresije. Analiza po Kawakiti ukazuje na to da se obrađeni lijek bolje preša od neobrađenog. Diferencijalna pretražna kalorimetrija (DSC) i Fourierova transformirana infracrvena spektroskopija (FTIR) pokazuju da sušenje raspršivanjem nije uzrokovalo nikakve kemijske promjene. Iz obrađenog metformina izrađene su tablete $(90 \% \mathrm{~m} / \mathrm{m})$ sa zadovoljavajućom lomljivošću, drobivošću i vremenom dezintegracije.

Ključne riječi: metformin hidroklorid, izravna kompresija, sušenje raspršivanjem

K. B. Institute of Pharmaceutical Education and Research, Gh-6 Road, Sector - 23, Gandhinagar-382023, Gujarat, India

L. M. College of Pharmacy, Opp. Gujarat University, Navrangpura, Ahmedabad-380009, Gujarat, India 